\title{
Community infrastructure and repository for marine magnetic identifications
}

\author{
Maria Seton ${ }^{1 *}$, Joanne Whittaker $^{2}$, Paul Wessel $^{3}$, R. Dietmar Müller ${ }^{1}$, Charles \\ DeMets $^{4}$, Sergey Merkouriev ${ }^{5}$, Steve Cande ${ }^{6}$, Carmen Gaina ${ }^{7}$, Graeme Eagles ${ }^{8}$, Roi \\ Granot $^{8}$, Joann Stock ${ }^{10}$, Nicky Wright ${ }^{1}$, Simon Williams ${ }^{1}$ \\ ${ }^{1}$ EarthByte Group, School of Geosciences, University of Sydney, NSW 2006, Sydney, Australia \\ ${ }^{2}$ Institute for Marine and Antarctic Studies, University of Tasmania, Hobart, Australia \\ ${ }^{3}$ SOEST, University of Hawai'i at Mānoa, 1680 East-West Rd., POST \#806, Honolulu, HI 96822, USA \\ ${ }^{4}$ Department of Geoscience, University of Wisconsin-Madison, Madison, WI 53706, USA \\ ${ }^{5}$ Pushkov Institute of Terrestrial Magnetism of the Russian Academy of Sciences, St Petersburg Filial. \\ 1 Mendeleevskaya Liniya, St Petersburg, 199034, Russia
${ }^{6}$ Scripps Institute of Oceanography, UCSD, 9500 Gilman Drive, La Jolla CA, 92093, USA
${ }^{7}$ Centre for Earth Evolution and Dynamics (CEED), University of Oslo Sem Sælands vei 24 P.O. Box 1048, Blindern NO-0316, Oslo, Norway
${ }^{8}$ Alfred Wegener Institute, Helmholtz Centre for Marine and Polar Research, Am Alten Hafen 26, D- \\ 27568 Bremerhaven, Germany \\ ${ }^{9}$ Department of Geological and Environmental Sciences, Ben Gurion University of the Negev, Beer \\ Sheva, Israel \\ ${ }^{10}$ Seismological Laboratory, California Institute of Technology, Pasadena, CA 91125 USA \\ * Corresponding author maria.seton@sydney.edu.au
}

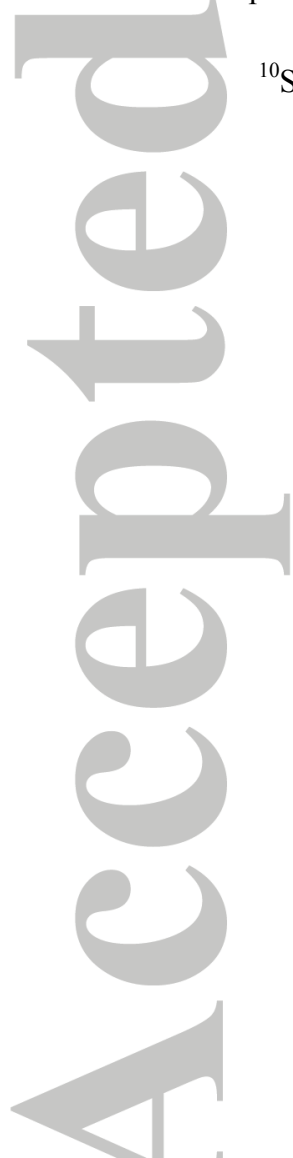

This article has been accepted for publication and undergone full peer review but has not been through the copyediting, typesetting, pagination and proofreading process which may lead to differences between this version and the Version of Record. Please cite this article as doi: 10.1002/2013GC005176 


\section{Abstract}

Magnetic anomaly identifications underpin plate tectonic reconstructions and form the primary dataset from which age of the oceanic lithosphere and seafloor spreading regimes in the ocean basins can be determined. Although these identifications are an invaluable resource, their usefulness to the wider scientific community has been limited due to the lack of a central community infrastructure to organize, host and update these interpretations. We have developed an open-source, community-driven online infrastructure as a repository for quality-checked magnetic anomaly identifications from all ocean basins. We provide a global sample dataset that comprises 96,733 individually picked magnetic anomaly identifications organized by ocean basin and publication reference, and provide accompanying Hellinger-format files, where available. Our infrastructure is designed to facilitate research in plate tectonic reconstructions or research that relies on an assessment of plate reconstructions, for both experts and non-experts alike. To further enhance the existing repository and strengthen its value, we encourage others in the community to contribute to this effort.

\section{Introduction}

Marine magnetic anomaly data are one of the primary data sources for the interpretation of seafloor spreading in the world's ocean basins and were instrumental in the development of the theory of plate tectonics (Dietz, 1961; Hess, 1962; Vine and

Matthews, 1963). These data record recognizable patterns formed due to reversals in the Earth's magnetic field over geological time. The majority of marine magnetic anomaly data, collected through marine ship track, aeromagnetic and helicopter 
surveys, have been made available to the scientific community through the GEODAS

(GEOphysical Data System) archive, developed by the US National Geophysical Data

Center (NGDC) (Sharman et al., 2001). A sub-set of these data, which have been

error-checked for observational outliers, excessive gradients, metadata consistency, and agreement with satellite altimetry-derived gravity and bathymetry grids (Chandler and Wessel, 2008, 2012) is available through the MGD77 supplement to the Generic Mapping Tools software suite (Wessel et al., 2013). Experts in marine geophysical data interpretation compare these magnetic anomaly data against synthetic crustal magnetic models and the geomagnetic reversal timescale to create a set of so-called magnetic anomaly identifications - a spatio-temporal representation of the magnetic anomalies themselves. From these magnetic anomaly identifications, the age and spreading regime of the ocean floor can be ascertained and a plate kinematic model constructed. Often, non-experts in marine geophysical data interpretation are interested in constructing and/or assessing alternative plate kinematic scenarios but lack the necessary expertise to interpret the raw data. Previous global and regional compilations of magnetic anomaly identifications have been presented as maps with no accompanying digital data (e.g.Karasik and Sochevanova, 1981; Karasik and Sochevanova, 1990; Ségoufin et al., 2004) limiting their usefulness for other researchers. The exception are the lineations of Cande et al. (1989) which are available through the NDGC website (www.ngdc.noaa.gov) but these are outdated and contain minimal metadata. An infrastructure that houses a freely available, downloadable repository of magnetic anomaly identifications that can be updated indefinitely is therefore of genuine value to the wider scientific community.

We have established a new infrastructure and repository for magnetic anomaly identification data. The infrastructure is open-source and community-driven, where 
consistent and well-documented information on magnetic anomaly identifications is

collected, quality-controlled and made accessible to the public via a dedicated website (www.soest.hawaii.edu/PT/GSFML). We have initially populated the repository with a global set of 96,733 published magnetic anomaly identifications (Fig. 1), and further additions will make the global database an evolving resource. A team of trusted, expert users are responsible for the addition and/or revision of contributions and overall management of the repository to ensure consistency and integrity of information. All information is stored under version control, allowing the history of the database to be reconstructed. The data are provided in three commonly used file formats: OGR/GMT multi-segment files, KMZ Google Earth files and ESRI Shapefiles. These data can be loaded directly into the plate reconstruction software, GPlates (Boyden et al., 2011), for visualization and interrogation or to construct or assess plate tectonic reconstructions. Where possible, we also provide any additional information (such as further details of the picking technique; the data source; processing techniques) in readme files for individual datasets. The infrastructure is complementary to the Global Fracture Zone database (Matthews et al., 2011), which enhances the power of the magnetic anomaly database for plate reconstruction studies.

\section{Magnetic anomaly identifications}

Marine magnetic anomaly identifications are an interpretation of the age of the oceanic crust, made by correlating individual magnetic anomaly patterns along profile against a synthetic crustal magnetic model and geomagnetic reversal timescale. The two-dimensional forward modeling of magnetic anomalies (e.g., Blakely (1995), Modmag (Mendel et al., 2005) and Magan (Schettino, 2012)) take into account factors that skew the shape of the magnetic anomalies such as remanent magnetization 
parameters, ambient geomagnetic field directions, spreading rates, spreading asymmetry and spreading ridge orientation. Synthetic models predominantly assume a vertical magnetized body. An alternative, but equivalent, approach is to de-skew (Schouten, 1971) the magnetic anomaly profiles taking into account the same parameters. The technique of "picking" magnetic anomalies and assigning their temporal component has been performed using methods that differ slightly in their design. This has led to inconsistencies in metadata assignment and storage, making it difficult to combine disparate studies into one self-consistent dataset. It is therefore often left to individual researchers to collate various datasets and ensure selfconsistency.

\subsection{Picking technique}

The picking technique employed for magnetic anomalies differs between researchers. Picking is made by eye on hard-copy printouts or digitally, or by using numerical approaches to "objectively" pick the location of the magnetic contrasts. Researchers commonly pick the "young" or "old" end of a magnetic chron (Fig. 2). As the geomagnetic reversal timescale is calibrated to the start and end of a magnetic chron, assigning an age to a magnetic anomaly identification based on this method is straightforward. In other cases, researchers pick the "center" or "middle" of an anomaly from which to make their magnetic anomaly identification, i.e. at the maximum or mid-point of the peak or trough that constitutes that anomaly (Fig. 2). This approach may be valuable in places where the edges of neighboring anomalies are unclear due to superposition owing to short isochron durations and/or slow spreading rates, even though correlating this type of identification with the geomagnetic reversal timescale becomes problematic. This information is usually depicted as "y", "o", "c" or "m" following the chron number. The absence of this 
information could potentially lead to tens of $\mathrm{km}$ of difference in the location/age association of a magnetic anomaly identification, with serious implications for plate motion studies. It is therefore crucial to preserve the chron end of each magnetic anomaly identification and also a measure of the confidence of this information.

An inherent assumption of magnetic anomaly identifications is that they are based on magnetic anomaly data recorded by elongated bodies formed by seafloor spreading parallel to the ridge axis. However, recent studies (e.g. Croon et al., 2008; Granot et al., 2009; Keller, 2004) have added additional picks using tectonic trends i.e., abyssal hills from high quality multibeam data. In these cases, two additional picks are identified on the edges of the swath multibeam to define three picks from a single voyage track. The identification method for each pick is noted to distinguish identifications not based on magnetic anomaly data.

\subsection{Magnetic chron and timescale}

The temporal component of a magnetic anomaly identification is based on a geomagnetic reversal timescale. Many alternative timescales exist (e.g. Cande and Kent, 1995; Gee and Kent, 2007; Gradstein et al., 1994; Gradstein et al., 2004; Heirtzler, 1968) and modifications continue as new constraints are obtained (e.g. Ogg and Lugowski, 2012). For this reason, the age of an identification is not explicitly stored but rather, we provide look-up tables for some commonly used timescales, such as (Cande and Kent, 1995; Gee and Kent, 2007; Gradstein et al., 2004), with the option of including other timescales in the future. A planned GMT5 supplement will provide tools to automate the look-up process.

\subsection{Rotation parameters}


Magnetic anomaly identifications, together with fracture zone traces, can be used to reconstruct palaeo-positions and direction of motion through time between two or more tectonic plates described by a rotation model. When two flanks of a spreading system are preserved, a series of stage or finite rotations can be computed using either a visual-fitting technique or, more robustly, the least-squares approach of Hellinger (1981) and Royer and Chang (1991) or Eagles (2004). These approaches compute rotations and their uncertainties based on a set of magnetic anomaly identifications, fracture zones segments, associated uncertainties and an approximate rotation pole position. The most-widely employed method to estimate uncertainties in plate reconstructions is that of Hellinger (1981). Our infrastructure has been designed to preserve, where available, input files for the "Hellinger" methodology (e.g. magnetic anomaly identifications, fracture zone segments) as well as the output files (e.g. the resultant rotations and covariance matrices). The "Hellinger" output can be converted to GROT format (Qin et al., 2012), the native rotation file format of the plate reconstruction software, GPlates.

2.4. Magnetic survey information

Ideally, magnetic anomaly interpretations are made along survey lines but this information is rarely preserved in digital magnetic anomaly identification compilations, especially for older datasets. Our infrastructure provides an optional field allowing for the survey line name to be preserved, such that individual magnetic anomaly identifications can easily be traced back to the original source data.

\subsection{Limitations}


Magnetic anomaly identifications are an interpretation of data, with errors stemming from a variety of sources: the original data itself; the interpretation technique; the way the information has been preserved. Source data errors have largely been addressed through error corrections applied to the NGDC data (Chandler and Wessel, 2008, 2012), but the errors originating from the source data remain as these corrections have not been propagated through to magnetic anomaly identifications made from the uncorrected data. Sources of error may derive from; errors in the location of the measurements, particular for old, pre-GPS data; large skewness angles due to magnetization and the ambient geomagnetic field directions; non-vertical magnetic boundaries within the magnetic source layer. Errors in the "picking" technique mainly arise from digitizing errors; the anomaly end assignment, especially if the centre-point of the anomaly was chosen or if this information is not explicitly stored; incorrect chron assignment; and low sampling resolution. Magnetic anomaly misinterpretations are possibly the largest sources of error but are difficult to quantify, especially if there are no alternative reconstructions for comparison. The association of Hellinger input and output files, where available, may provide confidence for one particular interpretation over another. The establishment of a community-driven repository with multiple, consistently formatted magnetic interpretations for each area may help partly overcome these limitations.

\section{The infrastructure and data repository}

Due to their close relationship, both fracture zone traces (and other seafloor fabric data) and the new magnetic anomaly and Hellinger-format files are accessible from the same top-level website (www.soest.hawaii.edu/PT/GSFML). Data files will be presented in GMT/OGR ASCII, KML, and shapefile formats for GMT, GPlates or 
general-purpose GIS software and will be distributed via zip files. We provide links to relevant plate reconstruction software and other tools from our site.

\section{Sample magnetic anomaly identification data from the world's oceans}

As part of our community magnetic anomaly identification repository, we provide a sample dataset of global identifications. This dataset has been quality-checked for consistency and only data attributable to a published data source is included. Our magnetic anomaly identification sample dataset is by no means complete but rather includes those data that have been provided freely to the community either through publication supplementary data, general online data repositories or through personal requests from the authors. Many more magnetic anomaly identifications exist that have yet to reach the public domain. Our intention for providing this sample data is to initiate the effort for a globally self-consistent magnetic anomaly identification repository.

\subsection{Atlantic Ocean}

We have collated magnetic anomaly identifications for the Cenozoic South Atlantic from Cande et al. (1988) and Müller et al. (1999), and from Rabinowitz and LaBrecque (1979) for the Mesozoic (Fig. 3a). In the southern South Atlantic, magnetic anomaly identifications associated with the Malvinas plate are from LaBrecque and Hayes (1979) and Marks and Stock (2001); the Cenozoic South America-Antarctic spreading corridors from LaBrecque and Cande (1986) and Livermore et al. (2005); and the early break-up of South America and Africa by Martin et al. (1982). The Mesozoic spreading in the Weddell Sea is represented by magnetic anomaly identifications from Kovacs et al. (2002). Magnetic anomaly

identifications for the North Atlantic are from Klitgord and Schouten (1986) for the 
Mesozoic-Cenozoic Central Atlantic; Müller et al. (1999) for the Cenozoic Central Atlantic; Klitgord and Schouten (1986) and Gaina et al. (2002) from IberiaNewfoundland to Greenland-Eurasia and the Labrador Sea; Srivastava and Tapscott (1986) and Gaina et al. (2002) for Greenland-Eurasia and the Eurasian Basin; and Srivastava and Tapscott (1986) and Gaina et al. (2009) for the Norway Basin (Fig. 3b). Numerous identifications of Neogene period reversals (20 Ma and younger) for the Arctic basin, the Kolbeinsey and Reykjanes Ridges, and the Mid-Atlantic Ridge north of the Azores triple junction are included from Merkouriev and DeMets (2008). Similarly detailed identifications of Neogene period reversals from the Africa-North America segment of the Mid-Atlantic Ridge $(15 \mathrm{~N}$ to $37 \mathrm{~N})$ are included from Merkouriev and DeMets (2014). The noticeable absence of magnetic anomaly identifications in the equatorial Atlantic is due to the combined effect of a north-south striking ridge and its position at the equator.

Where multiple magnetic anomaly identification datasets are available, we prefer the magnetic anomaly identifications of Müller et al. (1999) for the Cenozoic South Atlantic and Central Atlantic. In the North Atlantic a combination of identifications from Merkouriev and DeMets (2008) and Merkouriev and DeMets (2013) for Chron 6 and younger, and from Gaina et al. (2002) and Gaina et al. (2009) for reversals older than Chron 6, as the latter four studies each include rotations derived using the Hellinger method and rigorously estimated rotation uncertainties. In addition, the data for three of the studies (Gaina et al., 2009; Gaina et al., 2002; Merkouriev and DeMets, 2013) include fracture zone identifications based variously on multibeam, sonar, and satellite altimetry data.

4.2. Indian Ocean 
We have collated magnetic anomaly identifications in the Indian Ocean from a variety of sources. In the western Indian Ocean, these include Royer et al. (1988) for the Southwest Indian Ridge; Baines et al. (2007) for two detailed spreading corridor studies proximal to the Southwest Indian Ridge; DeMets et al. (2005) and Merkouriev and DeMets (2006) for the Central Indian and Carlsberg Ridges; Cande et al. (2010), Eagles and Hoang (2013) and Eagles and Wibisono (2013) for the Central Indian Basin; and Eagles and Konig (2008) for the Mesozoic spreading history (Fig. 3c). In the eastern Indian Ocean, these include Cande and Stock (2004), Tikku and Cande (1999), Veevers (1986), Granot et al. (2013) and Whittaker et al. (2007) for the southeast Indian Ridge; Gibbons et al. (2013) and Williams et al. (2013) for the Mesozoic Enderby Basin; and Mihut and Müller (1998), Müller et al. (1998) and Gibbons et al. (2012) for the Meoszoic anomalies along the western Australian margin (Fig. 3d). In addition, we incorporate a dataset covering the entire Indian Ocean from the Red Sea to the southeast Indian ridge from Segoufin et al. (2004) (Fig. 3c-d). We acknowledge the existence of many more unpublished magnetic anomaly identifications in the Indian Ocean (e.g. Yatheesh et al., 2013), which will be incorporated into our magnetic anomaly repository once they are published.

Where multiple magnetic anomaly identification datasets are available in the Indian Ocean we prefer a combination of Whittaker et al. (2007) and Tikku and Cande (1999) for the magnetic anomaly identifications in the southeast Indian Ocean, Cande et al. (2010) in areas of data overlap in the Central Indian Basin, the data of Gibbons et al. $(2012 ; 2013)$ for the Mesozoic eastern Indian Ocean, Royer et al. (1988) and Baines et al. (2007) for the southwest Indian Ridge and Eagles and Konig (2008) for the Mesozoic spreading between Africa, Madagascar and Antarctica. These interpretations were chosen as they were derived using newly collected data, recent 
fracture zone identifications, provide all the necessary metadata and/or incorporate uncertainties in derived rotations using the Hellinger method.

\subsection{Pacific Ocean}

The Pacific Ocean is vast and many of the magnetic anomaly identifications are old (pre-1980s), poorly documented and subject to larger data source and digitizing uncertainties than the more recent identifications found in many of the other ocean basins. We have collated magnetic anomaly identifications for the Mesozoic western Pacific from Nakanishi et al. (1992), Sharman and Risch (1988) and Atwater (1989) (Fig. 3e); the Mesozoic-Cenozoic northeast Pacific from Atwater (1989), Bassinger et al. (1969), Caress et al. (1988), Currie and Riddihough (1982), Elvers et al. (1967), Elvers et al. (1973), Klitgord and Mammerickx (1982), Mason and Raff (1961), Lonsdale (1991) and Vaquier et al. (1961); and the Cenozoic southeast Pacific from Atwater (1989), Barckhausen et al. (2013), Cande and Haxby (1991), Handschumacher (1976), Handschumacher (1981), Herron (1972), Klitgord and Mammerickx (1982), Mammerickx et al. (1980), Mayes et al. (1990), Munschy et al. (1996), Pardo-Casas and Molnar (1987), Tebbens and Cande (1997), Tebbens et al. (1997), Theberge (1971) and Weissel et al. (1977). Much recent focus has been on the remote Pacific-Antarctic spreading system due to its crucial role in the global plate circuit. Magnetic anomaly identifications have been made in the following publications: Croon et al. (2008), Larter et al. (2002), Wobbe et al. (2012) and Cande et al. (1995). Magnetic anomaly identifications for West Antarctic-Australia spreading in the Balleny corridor come from Cande et al. (2000), Cande and Stock (2004) and Granot et al. (2013), identifications from the Adare Trough representing spreading between East and West Antarctica come from Cande et al. (2000), Davey et al. (2006) and Granot et al. (2013), identifications around the Macquarie Ridge com 
from Keller (2004) . Finally, picks of Neogene period reversals from the northern end of the East Pacific Rise are included from DeMets and Traylen (2000).

Our preferred magnetic anomaly identifications for the southeast Pacific include a combination of the identifications from Barckhausen et al. (2013), Cande and Haxby (1991), Handschumacher (1976), Munschy et al. (1996), Pardo-Casas and Molnar (1987), Mammerickx et al. (1980), Tebbens and Cande (1997) and Weissel et al. (1977). For the northeast Pacific, our preferred magnetic anomaly identifications consist of a combination of interpretations from Atwater (1989), Bassinger et al. (1969), Elvers et al. (1967), Elvers et al. (1973) and Vaquier et al. (1961). Our preferred set of magnetic anomaly identifications for the Pacific-Antarctic ridge includes a combination of Croon et al. (2008), Wobbe et al. (2012) and Cande et al. (1995) as well as a few identifications from the earlier part of seafloor spreading from Larter et al. (2002) for the Pacific-Antarctic spreading system. We use the recent magnetic anomaly identifications for East-West Antarctic motion from Granot et al. (2013), which significantly reduces uncertainties in rotation parameters to define this motion compared to Cande et al. (2000).

\subsection{Backarc basins and marginal seas}

Seafloor spreading in back-arc basins and marginal seas produce identifiable magnetic anomalies even though spreading is often quite complex with chaotic seafloor spreading fabric, faster seafloor spreading rates and shorter time sequences of activity. In the southwest Pacific, we have collated the magnetic anomaly identifications for the Tasman Sea (Gaina et al., 1998), Coral Sea (Gaina et al., 1999) and North Loyalty and South Fiji Basins (Sdrolias et al., 2003). In southeast Asia, we incorporate the magnetic anomaly identifications for the South China Sea (Briais et al., 1993), Caroline Basin (Gaina and Müller, 2007) and the Parece Vela and Shikoku Basins 
(Sdrolias et al., 2004). We have collated magnetic anomaly identifications for the Scotia Sea from Barker and Burrell (1977) and Eagles et al. (2005) for the Drake Passage and Hill and Barker (1980) for the Sandwich plate, eastern Scotia Sea.

\section{Discussion and Conclusion}

Plate tectonic motion models provide the framework to place features on the Earth's surface in their spatio-temporal context and are important for assessing global and regional geological relationships and processes. These models are underpinned by magnetic anomaly and fracture zone interpretations. In addition, some key models of real value to the community rely directly on the constraints provided by magnetic anomaly identifications, e.g. the age of the ocean floor (Müller et al., 1997; Müller et al., 2008a), spreading rates and asymmetries (Müller et al., 2008a; Seton et al., 2009), predicted bathymetry (Müller et al., 2008b) and heatflow and hydrothermal flux (Müller et al., 2013).

The open-access, community-driven infrastructure that we have developed provides access to these fundamental constraints for the broader community. Our infrastructure allows for studies requiring the assessment of alternative plate reconstructions to be achieved by non-specialists or alternatively, for the specialist community to have access to previous interpretations of an area and assess which areas require further data collection and interpretation. We anticipate that the sample data provided with

this infrastructure will be continuously updated and we strongly encourage the community to contribute their magnetic anomaly identifications to this effort. 


\section{Acknowledgements}

We would like to extend thanks to the many researchers who have directly or indirectly contributed magnetic anomaly identifications to the wider community and

the NGDC for hosting the marine magnetic anomaly datasets. MS and JMW would like to thank support from Statoil, MS for support from Australian Research Council (ARC) grant DP0987713, RDM and SEW for support from ARC grant FL0992245, and PW for support from US National Science Foundation grant 0752543. CG acknowledges the Geological Survey of Canada and Geological Survey of Norway for their support and access to digital magnetic databases.

\section{Figures}

Figure 1: The global magnetic anomaly identification dataset that is provided as part of our infrastructure. Magnetic anomaly identifications are coloured by age based on the timescale of Gee and Kent (2007).

Figure 2: Schematic of how to "pick" a magnetic anomaly identification. We track the confidence in the anomaly end assignment using a numerical code, where $1=$ anomaly end clearly listed in the original paper; 2 - some problem exists from the original paper but there is confidence in the anomaly end assignment; 3 - anomaly end unclear in original paper and the end has been inferred.

Figure 3: Regional maps showing magnetic anomaly identification datasets, coloured by reference, which is how the data is provided in the repository.

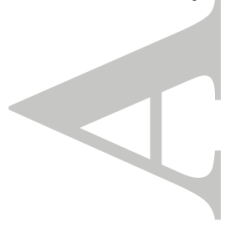

a. South Atlantic

b. North Atlantic 


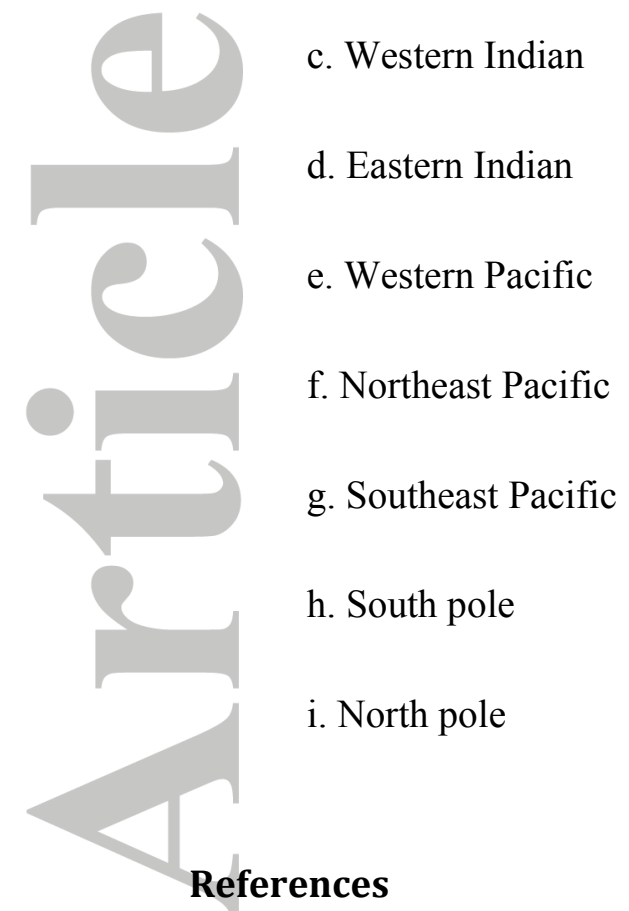

Atwater, T., 1989, Plate tectonic history of the northeast Pacific and western North America, in Winterer, E. L., Hussong, D. M., and Decker, R. W., eds., The Eastern Pacific Ocean and Hawaii, Volume N: Boulder, Colorado, Geological Society of America, p. 21-72.

Baines, A. G., Cheadle, M. J., Dick, H. J., Scheirer, A. H., John, B. E., Kusznir, N. J., and Matsumoto, T., 2007, Evolution of the Southwest Indian Ridge from 55 $45^{\circ} \mathrm{E}$ to $62^{\circ} \mathrm{E}$ : Changes in plate-boundary geometry since 26 Ma: Geochemistry, Geophysics, Geosystems, v. 8, no. 6.

Barckhausen, U., Bagge, M., and Wilson, D. S., 2013, Seafloor spreading anomalies and crustal ages of the Clarion-Clipperton Zone: Marine Geophysical Research, p. 1-10.

Barker, P., and Burrell, J., 1977, The opening of Drake passage: Marine geology, v. 25, no. 1, p. 15-34.

Bassinger, B., DeWald, O., and Peter, G., 1969, Interpretation of the magnetic anomalies off central California: Journal of Geophysical Research, v. 74, no. 6 , p. $1484-1487$.

Blakely, R., 1995, Potential Theory in Gravity and Magnetic Applications Cambridge Univ: Press, Cambridge.

Boyden, J. A., Müller, R. D., Gurnis, M., Torsvik, T. H., Clark, J. A., Turner, M., IveyLaw, H., Watson, R. J., and Cannon, J. S., 2011, Next-generation platetectonic reconstructions using GPlates, in Keller, G. R., and Baru, C., eds., Geoinformatics: Cyberinfrastructure for the Solid Earth Sciences: Cambridge, Cambridge University Press, p. 95-114.

Briais, A., Patriat, P., and Tapponnier, P., 1993, Updated interpretation of magnetic anomalies and seafloor spreading stages in the South China Sea: Implications for the Tertiary tectonics of Southeast Asia: Journal of Geophysical Research, v. 98, no. B4, p. 6299-6328.

Cande, S. C., and Haxby, W. F., 1991, Eocene propagating rifts in the southwest Pacific and their conjugate features on the Nazca plate: Journal of Geophysical Research, v. 96, no. B12, p. 19609-19622. 
Cande, S. C., and Kent, D. V., 1995, Revised calibration of the geomagnetic polarity timescale for the Late Cretaceous and Cenozoic: Journal of Geophysical Research, v. 100, no. B4, p. 6093-6095.

Cande, S. C., LaBrecque, J. L., and Haxby, W. F., 1988, Plate kinematics of the South Atlantic: Chron C34 to present: Journal of Geophysical Research, v. 93, no. B11, p. 13479-13492.

Cande, S. C., LaBrecque, J. L., Larson, R. L., Pitman, W. C., Golovchenko, X., and Haxby, W. F., 1989, Magnetic lineations of the world's ocean basins: American Association of Petroleum Geologists.

Cande, S. C., Patriat, P., and Dyment, J., 2010, Motion between the Indian, Antarctic and African plates in the early Cenozoic: Geophysical Journal International, v. 183, no. 1, p. 127-149.

Cande, S. C., Raymond, C. A., Stock, J., and Haxby, W. F., 1995, Geophysics of the Pitman fracture zone and Pacific-Antarctic plate motions during the Cenozoic: Science, v. 270, p. 947-953.

Cande, S. C., and Stock, J. M., 2004, Pacific-Antarctic-Australia motion and the formation of the Macquarie Plate: Geophysical Journal International, v. 157, no. 1, p. 399-414.

Cande, S. C., Stock, J. M., Müller, R. D., and Ishihara, T., 2000, Cenozoic motion between East and West Antarctica: Nature, v. 404, p. 145-150.

Caress, D. W., Menard, H., and Hey, R., 1988, Eocene reorganization of the PacificFarallon spreading center north of the Mendocino Fracture Zone: Journal of Geophysical Research: Solid Earth (1978-2012), v. 93, no. B4, p. 28132838.

Chandler, M. T., and Wessel, P., 2008, Improving the quality of marine geophysical track line data: Along-track analysis: Journal of Geophysical Research: Solid Earth (1978-2012), v. 113, no. B2.

- 2012, Errata-based correction of marine geophysical trackline data: Geochemistry, Geophysics, Geosystems, v. 13, no. 10.

Croon, M. B., Cande, S. C., and Stock, J. M., 2008, Revised Pacific-Antarctic plate motions and geophysics of the Menard Fracture Zone: Geochemistry, Geophysics, Geosystems, v. 9, p. 7.

Currie, R. G., and Riddihough, R., 1982, Geophysical Surveys in Northeast Pacific: AAPG Bulletin, v. 66, no. 7, p. 963.

Davey, F., Cande, S., and Stock, J., 2006, Extension in the western Ross Sea region - links between Adare Basin and Victoria Land Basin: Geophysical Research Letters, v. 33, no. 20.

DeMets, C., Gordon, R. G., and Royer, J.-Y., 2005, Motion between the Indian, Capricorn, and Somalian plates since $20 \mathrm{Ma}$ : implications for the timing and magnitude of distributed deformation in the equatorial Indian ocean: Geophys. J. Int., v. 161, p. 445-468.

DeMets, C., and Traylen, S., 2000, Motion of the Rivera plate since 10 Ma relative to the Pacific and North American plates and the mantle: Tectonoophysics, v. 318, p. 119-159.

Dietz, R. S., 1961, Evolution by Spreading of the Sea Floor: Nature, v. 190, no. 3, p. 854.

Eagles, G., 2004, Tectonic evolution of the Antarctic-Phoenix plate system since 15 Ma: Earth and Planetary Science Letters, v. 217, no. 1, p. 97-109. 
Eagles, G., and Hoang, H. H., 2013, Cretaceous to present kinematics of the Indian, African and Seychelles plates: Geophysical Journal International, p. $10.1093 /$ gji/ggt1372.

Eagles, G., and König, M., 2008, A model of plate kinematics in Gondwana breakup: Geophysical Journal International, v. 173, no. 2, p. 703-717.

Eagles, G., Livermore, R. A., Fairhead, J. D., and Morris, P., 2005, Tectonic evolution of the west Scotia Sea: Journal of Geophysical Research: Solid Earth (1978-2012), v. 110, no. B2.

Eagles, G., and Wibisono, A. D., 2013, Ridge push, mantle plumes and the speed of the Indian plate: Geophysical Journal International, v. 194, no. 2, p. 670677.

Elvers, D., Peter, G., and Moses, R., 1967, Analysis of magnetic linearions in the North Pacific: Trans. Am. Geophys. Union, v. 48, p. 89.

Elvers, D., Srivastava, S., Potter, K., Morley, J., and Sdidel, D., 1973, Asymmetric spreading across the Juan de Fuca and Gorda rises as obtained from a detailed magnetic survey: Earth and Planetary Science Letters, v. 20, no. 2, p. 211-219.

Gaina, C., Gernigon, L., and Ball, P., 2009, Palaeocene-Recent plate boundaries in the NE Atlantic and the formation of the Jan Mayen microcontinent: Journal of the Geological Society, v. 166, no. 4, p. 601.

Gaina, C., Müller, D. R., Royer, J. Y., Stock, J., Hardebeck, J., and Symonds, P., 1998, The tectonic history of the Tasman Sea: a puzzle with 13 pieces: Journal of Geophysical Research, v. 103, no. B6, p. 12413-12433.

Gaina, C., and Müller, R. D., 2007, Cenozoic tectonic and depth/age evolution of the Indonesian gateway and associated back-arc basins: Earth-Science Reviews, v. 83, no. 3-4, p. 177-203.

Gaina, C., Müller, R. D., Royer, J.-Y., and Symonds, P., 1999, The tectonic evolution of the Louisiade Triple Junction: Journal of Geophysical Research, v. 104, p. 12973-12939.

Gaina, C., Roest, W. R., and Muller, R. D., 2002, Late Cretaceous-Cenozoic deformation of northeast Asia: Earth and Planetary Science Letters, v. 197, no. 3-4, p. 273-286.

Gee, J. S., and Kent, D. V., 2007, Source of oceanic magnetic anomalies and the geomagnetic polarity time scale: Treatise on Geophysics, vol. 5: Geomagnetism, p. 455-507.

Gibbons, A., Barckhausen, U., van den Bogaard, P., Hoernle, K., Werner, R., Whittaker, J. M., and Müller, R. D., 2012, Constraining the Jurassic extent of Greater India: tectonic evolution of the Australian margin: Geochemistry, Geophyics, Geosystems, v. 13, no. 5.

Gibbons, A. D., Whittaker, J. M., and Dietmar Müller, R., 2013, The breakup of East Gondwana: assimilating constraints from Cretaceous ocean basins around India into a best - fit tectonic model: Journal of Geophysical Research, v. 118, p. 1-15.

Gradstein, F. M., Agterberg, F. P., Ogg, J. G., Hardenbol, S., Vanveen, P., Thierry, J., and Huang, Z. H., 1994, A Mesozoic time scale: Journal of Geophysical Research-Solid Earth, v. 99, no. B12, p. 24051-24074.

Gradstein, F. M., Ogg, J., Smith, A., Agterberg, F., Bleeker, W., Cooper, R., Davydov, V., Gibbard, P., Hinnov, L., and House, M., 2004, A geologic time scale, Cambridge University Press. 
Granot, R., Cande, S., Stock, J., and Damaske, D., 2013, Revised Eocene - Oligocene kinematics for the West Antarctic rift system: Geophysical Research Letters, v. 40, no. 2, p. 1-6.

Granot, R., Cande, S. C., and Gee, J. S., 2009, The implications of long-lived asymmetry of remanent magnetization across the North Pacific fracture zones: Earth and Planetary Science Letters, v. 288, no. 3, p. 551-563.

Handschumacher, D., Pilger, R., Foreman, J., and Campbell, J., 1981, Structure and evolution of the Easter plate: Mem. Geol. Soc. Am, v. 154, p. 63-76.

Handschumacher, D. W., 1976, Post-Eocene plate tectonics of the Eastern Pacific, in Sutton, G. H., ed., The Geophysics of the Pacific Ocean Basin and Its Margin, Geophys. Monogr. Ser, Volume 19, American Geophysical Union, Washington D.C.

Heirtzler, J. R., G.O. Dickson, E.M. Herman, W.C. Pitman III and X. LePichon, 1968, Marine Magnetic Anomalies, Geomagnetic Field Reversals, and Motions of the Ocean Floor and Continents: Journal of Geophysical Research, v. 73, p. 2119-2136.

Hellinger, S. J., 1981, The uncertainties of finite rotations in plate tectonics: J. Geophys. Res., v. 86, no. B10, p. 9312-9318.

Herron, E. M., 1972, Sea-floor spreading and the Cenozoic history of the eastcentral Pacific: Geological Society of America Bulletin, v. 83, no. 6, p. 16711692.

Hess, H. H., 1962, History of Ocean Basins: Geological Society of America Bulletin; Petrologic Studies: A Volume to Honour A.F. Buddington, p. 559-620.

Hill, I. A., and Barker, P. F., 1980, Evidence for Miocene back-arc spreading in the central Scotia Sea: Geophysical Journal International, v. 63, no. 2, p. 427440.

Karasik, A. M., and Sochevanova, N. A., 1981, Axes of magnetic anomalies on the World Ocean water area. , Collection of articles: Electromagnetic Studies of the Earth Crust and the Upper Mantle in Ocean and Seas: Moscow (in Russian). IZMIRAN, p. 205-212.

Karasik, A. M., and Sochevanova, N. A., 1990, International GeologicalGeophysical Atlas of the Atlantic Ocean (maps 47, 48, 50, 54): UNESCO, Intergovermental Oceanographie Commission.

Keller, W. R., 2004, Cenozoic plate tectonic reconstructions and plate boundary processes in the Southwest Pacific [PhD: California Institute of Technology, $139 \mathrm{p}$.

Klitgord, K., and Schouten, H., 1986, Plate kinematics of the central Atlantic, in Vogt, P. R., and Tucholke, B. E., eds., The Western North Atlantic Region, DNAG: Boulder, CO, Geol. Soc. Am., p. 351-378.

Klitgord, K. D., and Mammerickx, J., 1982, Northern East Pacific Rise: magnetic anomaly and bathymetric framework: Journal of Geophysical Research, v. 87, no. B8, p. 6725-6750.

Kovacs, L. C., Morris, P., Brozena, J., and Tikku, A., 2002, Seafloor spreading in the Weddell Sea from magnetic and gravity data: Tectonophysics, v. 347, no. 1-3, p. 43-64.

LaBrecque, J. L., and Cande, S. C., 1986, Total intensity magnetic anomaly profiles, Northwest Ocean Margin Drilling Program, Regional Data Synthesis Series, Atlas 13, S: Atlantic Ocean and Adjacent Antarctic Continental Margin. 
LaBrecque, J. L., and Hayes, D. E., 1979, Seafloor spreading history of the Agulhas Basin: Earth and Planetary Science Letters, v. 45, p. 411-428.

Larter, R. D., Cunningham, A. P., Barker, P. F., Gohl, K., and Nitsche, F. O., 2002, Tectonic evolution of the Pacific margin of Antarctica 1. Late Cretaceous tectonic reconstructions: Journal of Geophysical Research-Solid Earth, v. 107, no. B12, p. 2345-2345.

Livermore, R., Nankivell, A., Eagles, G., and Morris, P., 2005, Paleogene opening of Drake Passage: Earth and Planetary Science Letters, v. 236, p. 459-470.

Lonsdale, P., 1991, Structural patterns of the Pacific floor offshore of peninsular California: The gulf and peninsular province of the Californias, v. 47, p. 87125.

Mammerickx, J., Herron, E., and Dorman, L., 1980, Evidence for two fossil spreading ridges in the southeast Pacific: Geological Society of America Bulletin, v. 91, no. 5, p. 263-271.

Marks, K., and Stock, J., 2001, Evolution of the Malvinas Plate south of Africa: Marine Geophysical Researches, v. 22, no. 4, p. 289-302.

Martin, A., Goodlad, S., Hartnady, C., and Du Plessis, A., 1982, Cretaceous palaeopositions of the Falkland Plateau relative to southern Africa using Mesozoic seafloor spreading anomalies: Geophysical Journal International, v. 71, no. 3, p. 567-579.

Mason, R. G., and Raff, A. D., 1961, Magnetic survey off the west coast of North America, $32 \mathrm{~N}$. latitude to $42 \mathrm{~N}$. latitude: Geological Society of America Bulletin, v. 72, no. 8, p. 1259-1265.

Matthews, K. J., Müller, R. D., Wessel, P., and Whittaker, J. M., 2011, The tectonic fabric of the ocean basins: Journal of Geophysical Research: Solid Earth, v. 116, no. B12.

Mayes, C. L., Lawver, L. A., and Sandwell, D. T., 1990, Tectonic history and new isochron chart of the South Pacific: Journal of Geophysical Research, v. 95, no. B6, p. 8543-8567.

Mendel, V., Munschy, M., and Sauter, D., 2005, MODMAG, a MATLAB program to model marine magnetic anomalies: Computers \& geosciences, v. 31 , no. 5 , p. 589-597.

Merkouriev, S., and DeMets, C., 2006, Constraints on Indian plate motion since 20 Ma from dense Russian magnetic data: Implications for Indian plate dynamics: Geochem. Geophys. Geosyst., v. 7, no. doi:10.1029/2005GC001079.

- 2008, A high-resolution model for Eurasia-North America plate kinematics since 20 Ma: Geophys. J. Int., v. 173, p. 1064-1083.

,- 2013 , High-resolution estimates of Nubia-North America plate motion: $20 \mathrm{Ma}$ to present: Geophysical Journal International, v. doi:10.1093/gji/ggt463.

Mihut, D., and Müller, R. D., 1998, Revised seafloor spreading history of the Argo Abyssal Plain, West Australian Basins Symposium 98: Perth.

Müller, R. D., Cande, S. C., Royer, J.-Y., Roest, W. R., and Maschenkov, S., 1999, New constraints on the Late Cretaceous/Tertiary plate tectonic evolution of the Caribbean, in Mann, P., ed., Caribbean Basins, Volume 4: Amsterdam, Elsevier, p. 39-55.

Müller, R. D., Dutkiewicz, A., Seton, M., and Gaina, C., 2013, Seawater chemistry driven by supercontinent assembly, breakup, and dispersal: Geology, v. 41, no. 8, p. 907-910. 
Müller, R. D., Mihut, D., and Baldwin, S., 1998, A new kinematic model for the formation and evolution of the Northwest and West Australian margin, in R.R, P. P. G. a., ed., The sedimentary basins of western Australia 2: Perth, Petroleum Exploration Society of Australia, p. 55-72.

Müller, R. D., Roest, W. R., Royer, J.-Y., Gahagan, L. M., and Sclater, J. G., 1997, Digital isochrons of the world's ocean floor: Journal of Geophysical Research, v. 102, p. 3211-3214.

Müller, R. D., Sdrolias, M., Gaina, C., and Roest, W. R., 2008a, Age, spreading rates, and spreading asymmetry of the world's ocean crust: Geochem. Geophys. Geosyst., v. 9, no. Q04006, p. doi:10.1029/2007GC001743.

Müller, R. D., Sdrolias, M., Gaina, C., Steinberger, B., and Heine, C., 2008b, Longterm sea level fluctuations driven by ocean basin dynamics: Science, v. 319, no. 5868, p. 1357-1362.

Munschy, M., Antoine, C., and Gachon, A., 1996, Tectonic evolution in the Tuamotu Islands Region, Central Pacific Ocean: C R Acad Sci Ser II A, v. 323, no. 11, p. 941-948.

Nakanishi, M., Tamaki, K., and Kobayashi, K., 1992, Magnetic anomaly lineations from Late Jurassic to Early Cretaceous in the west central Pacific Ocean: Geophys. J. Int., v. 109, no. 3, p. 701-719.

Ogg, J., and Lugowski, A., 2012, TSCreator visualization of enhanced Geologic Time Scale 2004 database (Version 6.0): Available at: http://www.tscreator.org.

Pardo-Casas, F., and Molnar, P., 1987, Relative motion of the Nazca (Farallon) and South American plates since Late Cretaceous time: Tectonics, v. 6, no. 3, p. 215-232.

Qin, X., Müller, R., Cannon, J., Landgrebe, T., Heine, C., Watson, R., and Turner, M., 2012, The GPlates Geological Information Model and Markup Language: Geoscientific Instrumentation, Methods and Data Systems Discussions, v. 2, p. 365-428.

Rabinowitz, P. D., and LaBrecque, J., 1979, The Mesozoic South Atlantic Ocean and evolution of its continental margins: Journal of Geophysical Research: Solid Earth (1978-2012), v. 84, no. B11, p. 5973-6002.

Royer, J.-Y., and Chang, T., 1991, Evidence for relative motions between the Indian and Australian plates during the last 20 m.y. from plate tectonic reconstructions: Implications for the deformation of the Indo-Australian plate: J. Geophys. Res, v. 96, no. B7, p. 11779-11802.

Royer, J.-Y., Patriat, P., Bergh, H., and Scotese, C. R., 1988, Evolution of the Southwest Indian Ridge from the Late Cretaceous (anomaly 34) to the middle Eocene (anomaly 20): Tectonophysics, v. 155, p. 235-260.

Schettino, A., 2012, Magan: A new approach to the analysis and interpretation of marine magnetic anomalies: Computers \& Geosciences, v. 39, p. 135-144.

Schouten, H., 1971, A fundamental analysis of magnetic anomalies over midocean ridges: Marine Geophysical Researches, v. 1, p. 111-144.

Sdrolias, M., Müller, R. D., and Gaina, C., 2003, Tectonic Evolution of the SW Pacific Using Constraints from Back-arc Basins, in Hillis, R. R., and Müller, R. D., eds., Evolution and Dynamics of the Australian Plate, Volume 22, Geological Society of Australia Special Publication and Geological Society of America Special Paper. 
Sdrolias, M., Roest, W. R., and Müller, R. D., 2004, An Expression of Philippine Plate Rotation: the Parece Vela and Shikoku Basins: Tectonophysics, v. 394, p. 69-86.

Ségoufin, J., Munschy, M., Bouysse, P., and Mendel, V., 2004, Map of the Indian Ocean (1: 20000 000), sheet 1:"Physiography", sheet 2:"Structural map": CGMW Edition, Paris.

Seton, M., Gaina, C., Müller, R. D., and Heine, C., 2009, Mid-Cretaceous seafloor spreading pulse: fact or fiction?: Geology, v. 37, no. 8, p. 687-690.

Sharman, G., Divins, D., Metzger, D., and Campagnoli, J., NGDC Marine Geophysical Data Systems: Past, Present, and Future, in Proceedings AGU Fall Meeting Abstracts2001, Volume 1, p. 0357.

Sharman, G., and Risch, D., 1988, Northwest Pacific tectonic evolution in the Middle Mesozoic: Tectonophysics, v. 155, no. 1, p. 331-344.

Srivastava, S., and Tapscott, C., 1986, Plate kinematics of the North Atlantic The Geology of North America, M, in Vogt, P., and Tucholke, B., eds., The Western North Atlantic Region, p. 379-404.

Tebbens, S., Cande, S., Kovacs, L., Parra, J., LaBrecque, J., and Vergara, H., 1997, The Chile ridge: A tectonic framework: Journal of Geophysical Research, v. 102, no. B6, p. 12035-12012,12059.

Tebbens, S. F., and Cande, S. C., 1997, Southeast Pacific Tectonic Evolution From Early Oligocene to Present: Journal of Geophysical Research-Solid Earth, v. 102, no. B6, p. 12061-12084.

Theberge, A. E., Jr., 1971, Magnetic survey off southern California and Baja California: National Oceanographic and Atmospheric Administration, National Ocean Survey.

Tikku, A. A., and Cande, S. C., 1999, The oldest magnetic anomalies in the Australian-Antarctic Basin: Are they isochrons?: Journal of Gephysical Research, v. 104, p. 661-677.

Vacquier, V., Raff, A. D., and Warren, R. E., 1961, Horizontal displacements in the floor of the northeastern Pacific Ocean: Geological Society of America Bulletin, v. 72, no. 8, p. 1251-1258.

Veevers, J., 1986, Breakup of Australia and Antarctica estimated as midCretaceous $(95 \pm 5 \mathrm{Ma}$ ) from magnetic and seismic data at the continental margin: Earth and Planetary Science Letters, v. 77, no. 1, p. 91-99.

Vine, F. J., and Matthews, D. H., 1963, Magnetic anomalies over oceanic ridges: Nature, v. 4897, p. 947-949.

Weissel, J. K., Hayes, D. E., and Herron, E. M., 1977, Plate tectonics synthesis: The displacements between Australia, New Zealand, and Antarctica since the late Cretaceous: Marine geology, v. 25, no. 1, p. 231-277.

Wessel, P., Smith, W. H. F., Scharroo, R., Luis, J. F., and Wobbe, F., 2013, Generic Mapping Tools: Improved version released: Eos Trans. AGU, v. 94, no. 45, p. 409-410.

Whittaker, J., Müller, R. D., Leitchenkov, G., Stagg, H., Sdrolias, M., Gaina, C., and Goncharov, A., 2007, Major Australian-Antarctica Plate Reorganization at Hawaiian-Emperor Bend Time: Science, v. 318, p. 83-86.

Williams, S. E., Whittaker, J. M., Granot, R., and Müller, R. D., 2013, Early IndiaAustralia spreading history revealed by newly detected Mesozoic magnetic anomalies in the Perth Abyssal Plain: Journal of Geophysical Research, p. doi: 10.1002/jgrb.50239. 
Wobbe, F., Gohl, K., Chambord, A., and Sutherland, R., 2012, Structure and breakup history of the rifted margin of West Antarctica in relation to Cretaceous separation from Zealandia and Bellingshausen plate motion: Geochemistry, Geophysics, Geosystems, v. 13, no. 4.

Yatheesh, V., Dyment, J., Bhattacharya, G. C., and Muller, R. D., 2013, Deciphering detailed plate kinematics of the Indian Ocean and developing a unified model for East Gondwanaland reconstruction: An Indian-AustralianFrench initiative: Deep Continental Studies in India: Newsletter, v. 23, no. 1, p. 2-9.

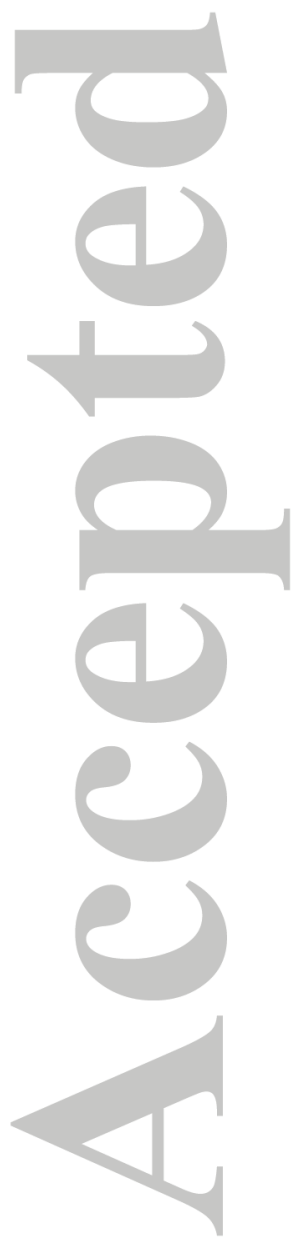




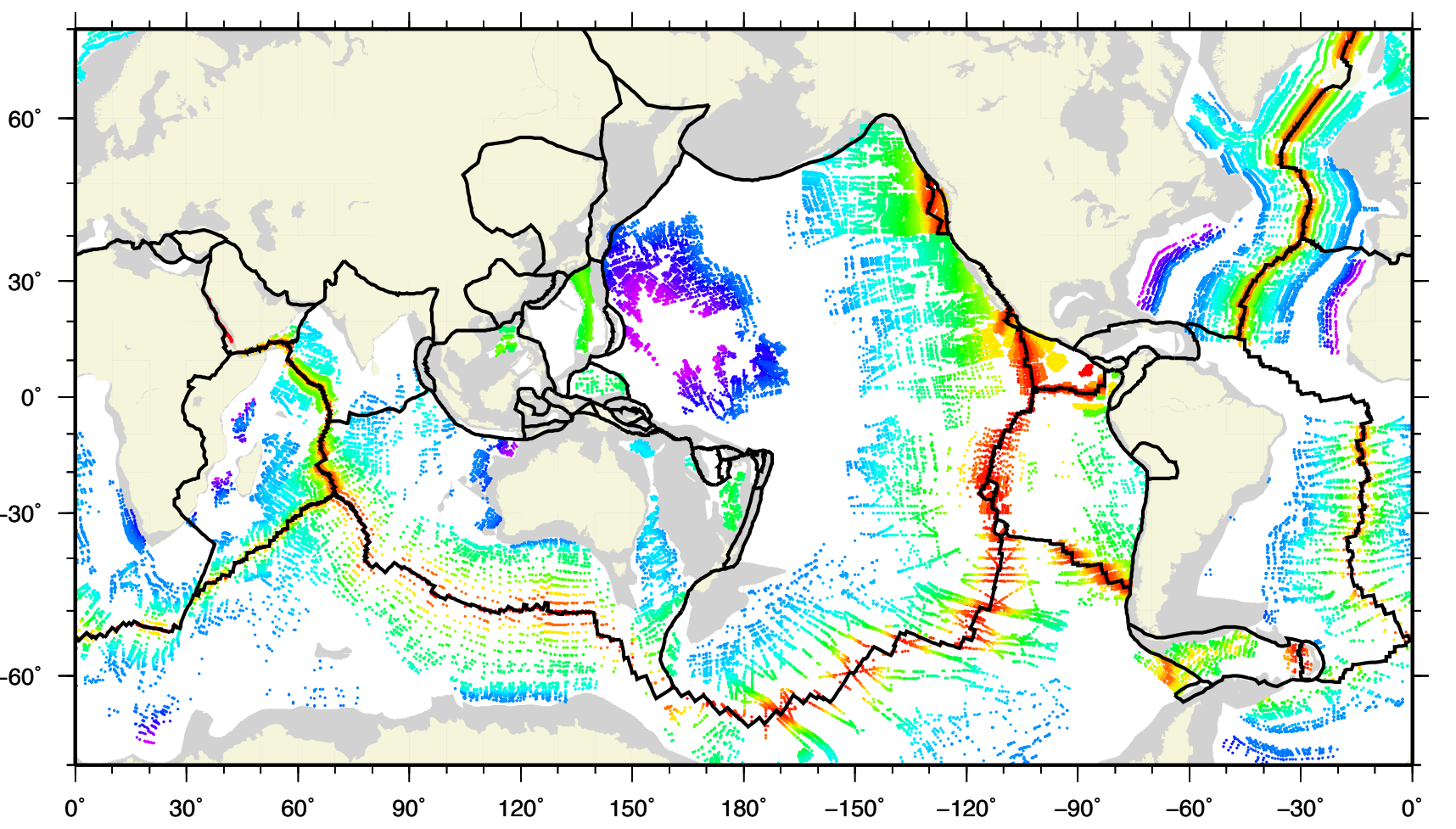




\section{centre or middle point "c" or " $\mathrm{m}$ "}
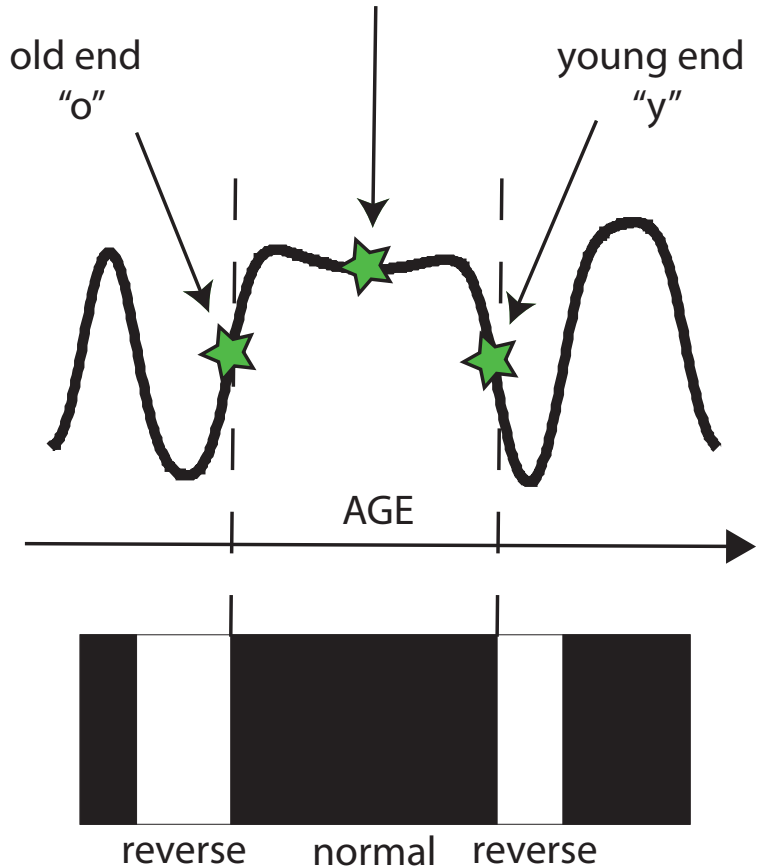


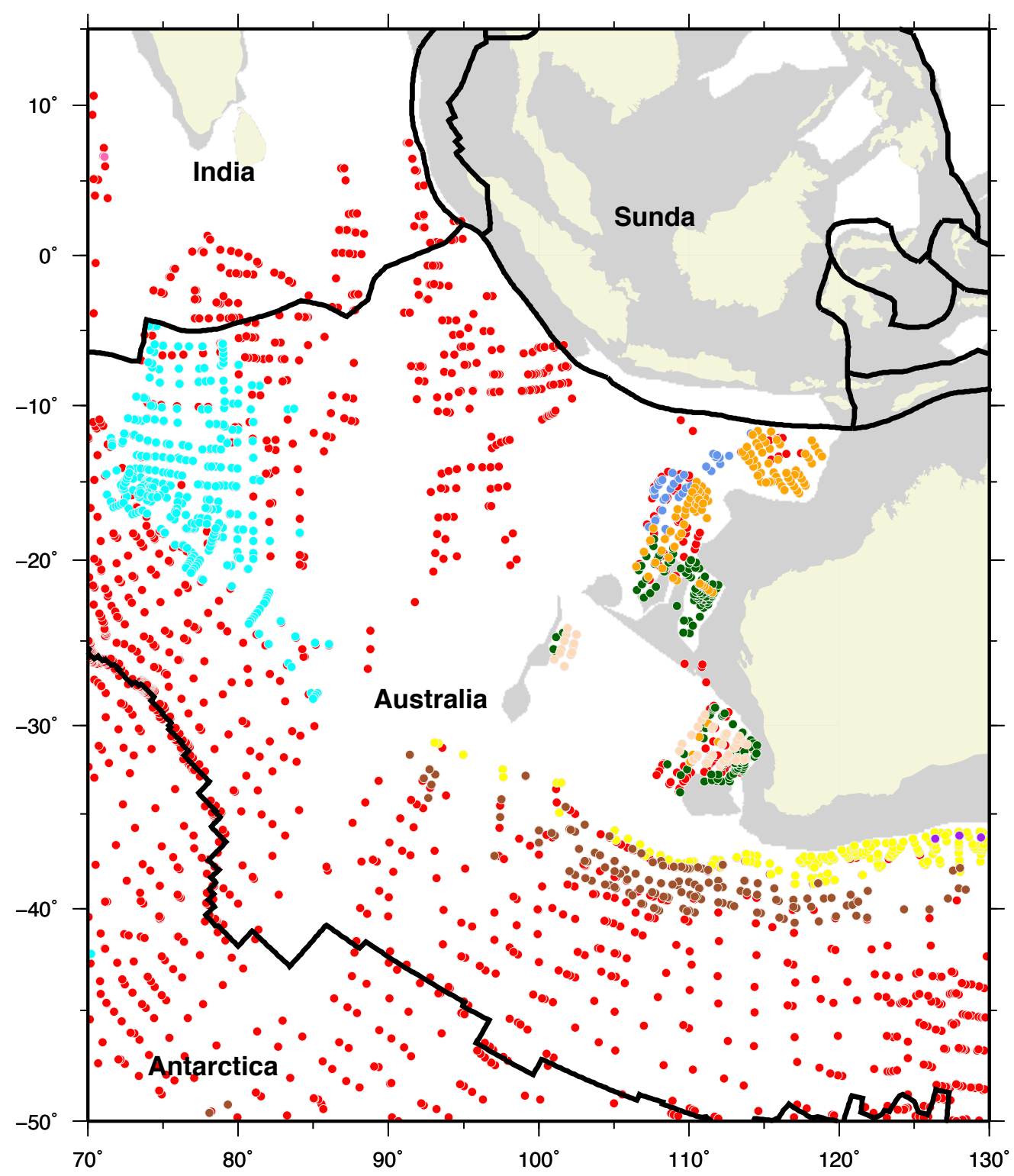




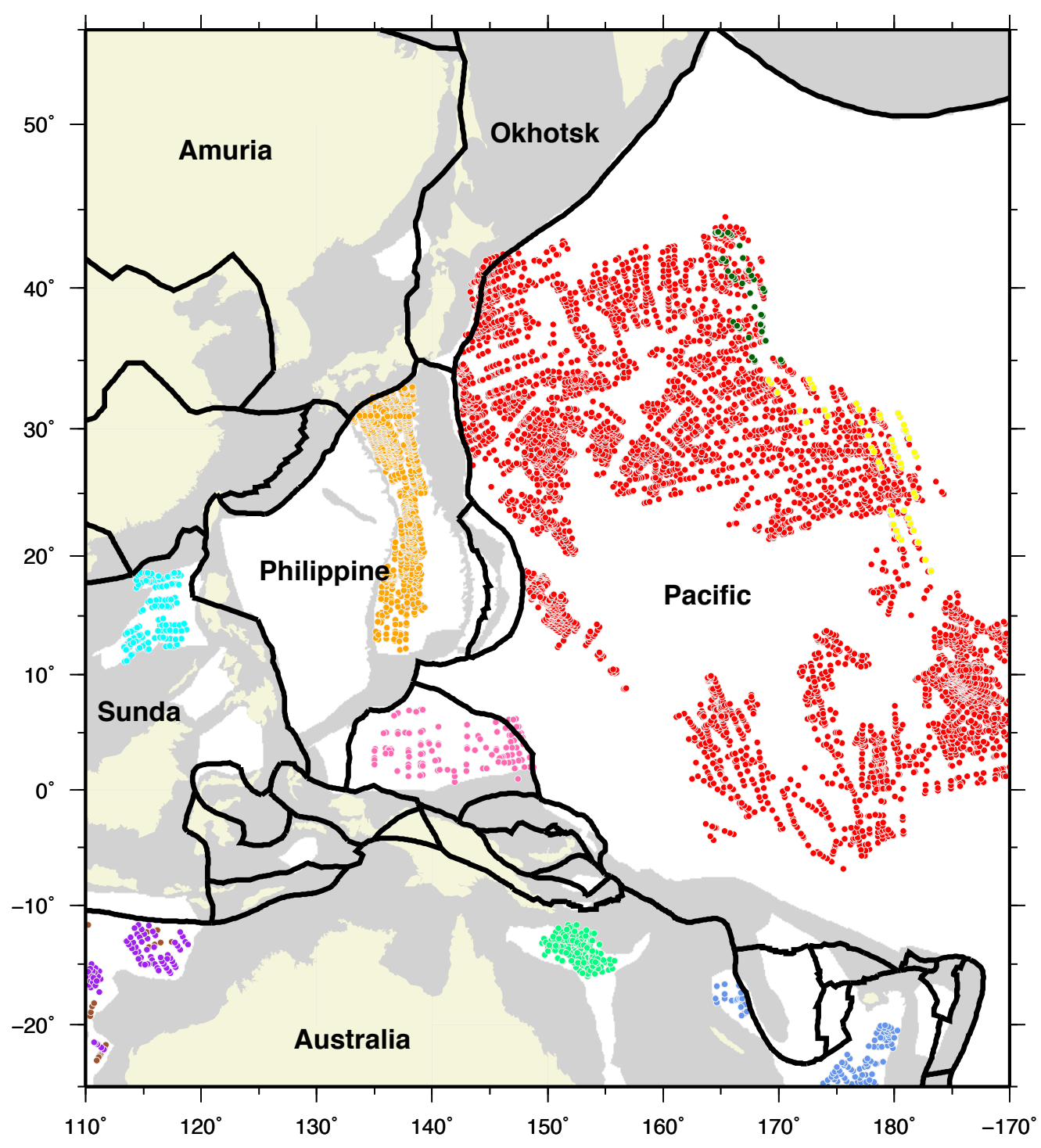





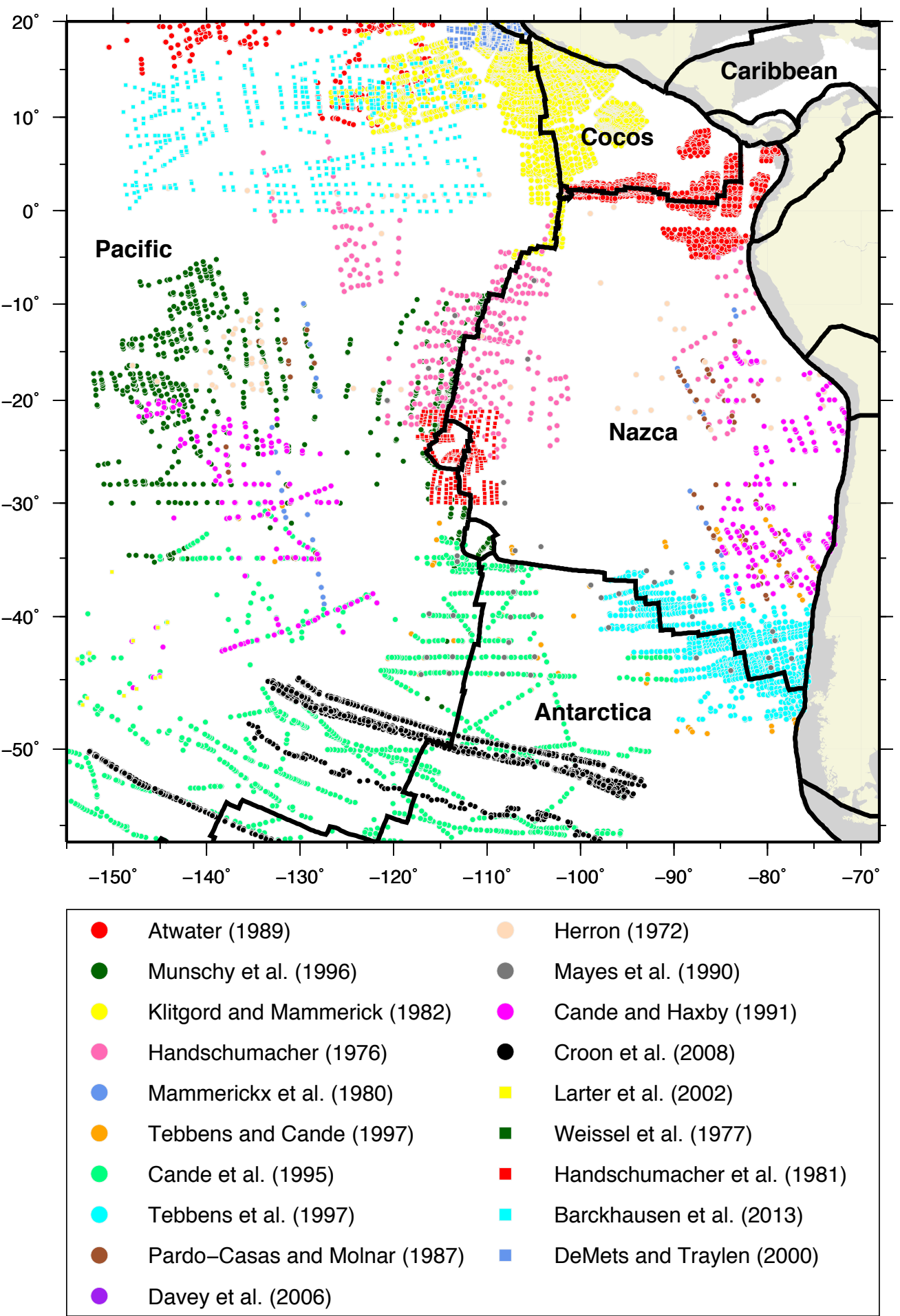




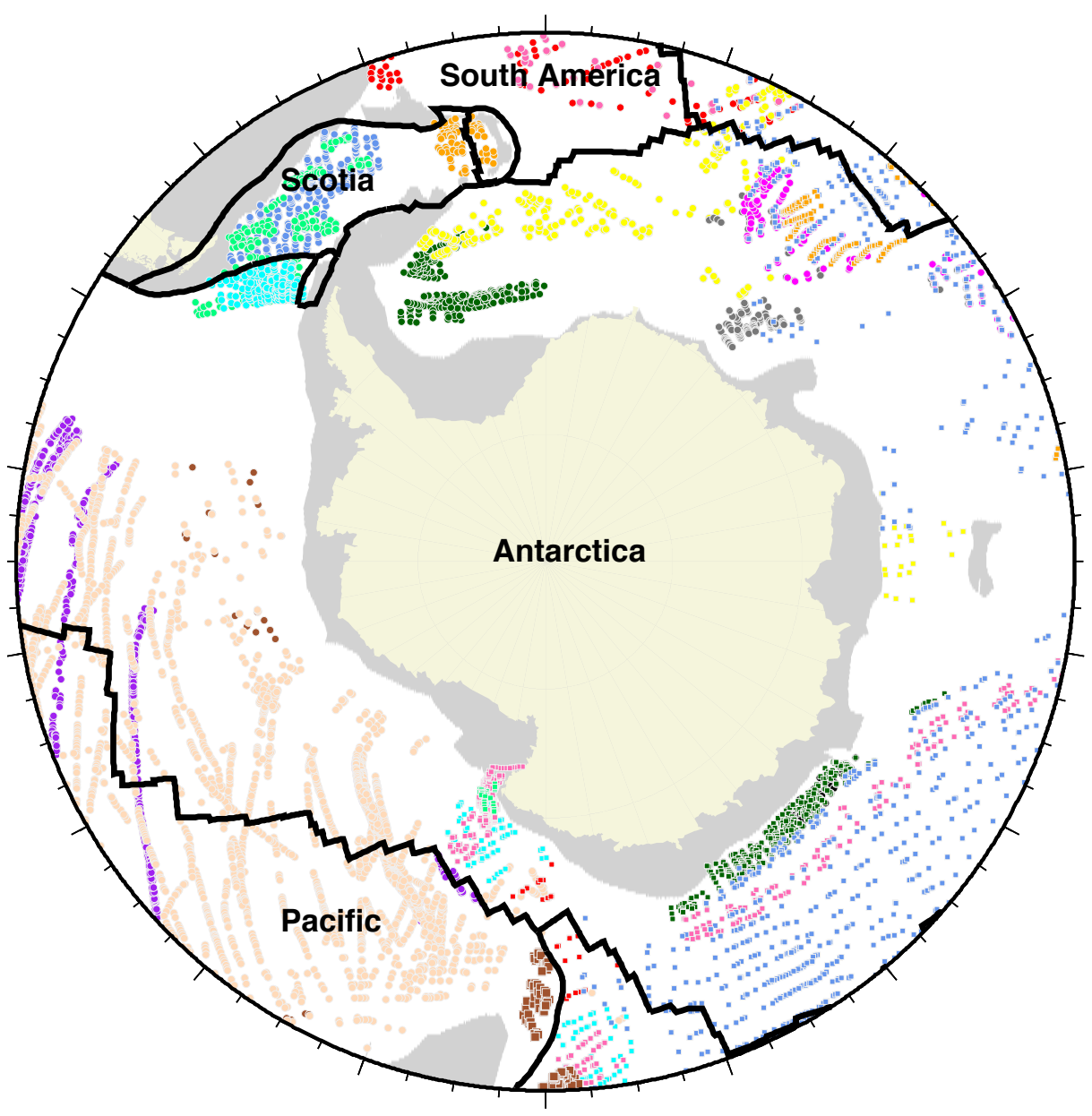

- Cande et al. (1988)

- Kovacs et al. (2002)

LaBreque and Cande (1986)

Muller et al. (1999)

Eagles et al. (2005)

Hill and Barker (1980)

Barker and Burell (1977)

Eagles et al. (2004)

Larter et al. (2002)

Croon et al. (2008)

Cande et al. (1995)
Royer et al. (1988)

- Whittaker et al. (2007)

Gibbons et al. (2012)

- Tikku and Cande (1999)

- Cande and Stock (2004)

Cande and Stock (2000)

Granot et al. (2013)

- Segoufin et al. (2004)

- Cande et al. (2010)

Davey et al. (2006)

- Keller (2004)

- Eagles and Koenig (2008) 


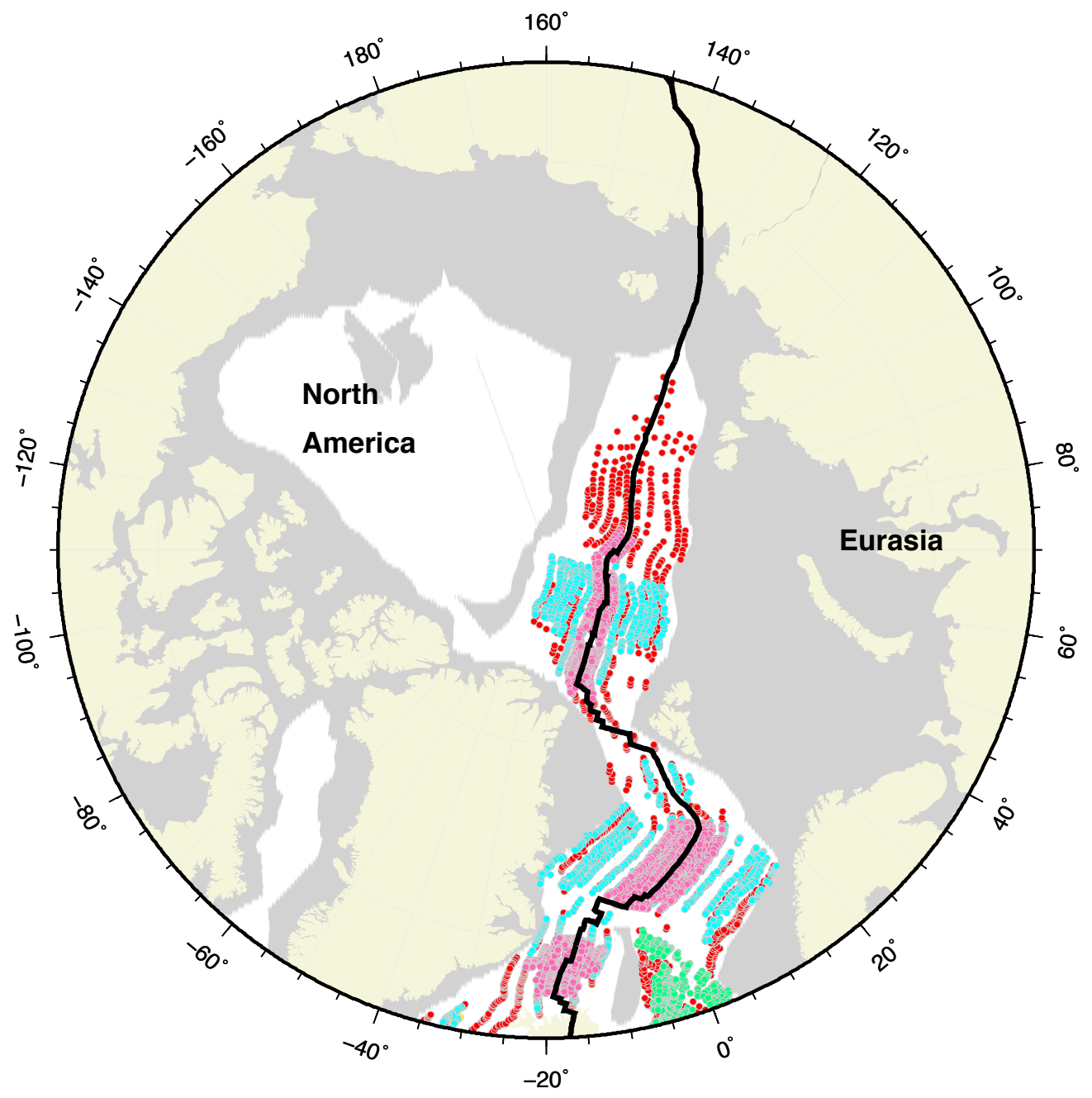

- Srivastava and Tapscott (1986) Gaina et al. (2002)

Klitgord and Schouten (1986) @ Gaina et al. (2009)

- Merkouriev and DeMets (2008) 